\title{
FITOREMEDIASI LOGAM TIMBAL (Pb) DENGAN MENGGUNAKAN HYDRILLA VERTICILLATA DAN NAJAS INDICA
}

\author{
Fadila Mutmainnah $^{1}$, Arinafril $^{2}$, Suheryanto $^{3}$ \\ ${ }^{1}$ Jurusan Biologi Lingkungan Program Studi Pengelolaan Lingkungan PascaSarjana \\ Universitas Sriwijaya \\ ${ }^{2}$ Jurusan Hama dan Penyakit Tumbuhan Fakultas Pertanian Universitas Sriwijaya \\ ${ }^{3}$ Jurusan Kimia Fakultas MIPAUniversitas Sriwijaya \\ email: fadilamutmainnah2@gmail.com
}

\begin{abstract}
ABSTRAK
Fitoremediasi merupakan salah satu upaya mereduksi cemaran Timbal $(\mathrm{Pb})$ dari perairan dengan memanfaatkan tumbuhan. Hydrilla verticillata dan Najas indica merupakan tumbuhan air yang tergolong submerge yang banyak dijumpai di Sumatera Selatan. Penelitian ini dilakukan di Laboratorium Riset Terpadu PascaSarjana Universitas Sriwijaya. Rancangan penelitian yang digunakan pada penelitian ini adalah Rancangan Acak Lengkap (RAL) dengan pola faktorial dengan 2 faktor, yaitu macam jenis tanaman yaitu Hydrilla verticillata dan Najas indica, serta macam konsentrasi yaitu kontrol, $5 \mathrm{mg} / \mathrm{l}, 10 \mathrm{mg} / \mathrm{l}, 15 \mathrm{mg} / \mathrm{l}$. Perlakuan ini dilakukan dengan 3 kali ulangan. Analisa kandungan Pb didalam tumbuhan dan di dalam air dilakukan pada hari ke - 5, hari ke - 10, hari ke - 15 dan hari ke - 20 dengan metode analisa AAS yang dilakukan di di laboratorium penelitian Jurusan Kimia, Fakultas MIPA, Universitas Sriwijaya. Hasil yang diperoleh dari analisa laboratorium dilakukan Analisis Varian (ANAVA), jika berpengaruh nyata dilanjutkan dengan uji Duncans (DNMRT) pada taraf 5\% dan dilakukan perhitungan kecepatan penyerapan Hydrilla verticillata dan Najas indica. Hasil penelitian menunjukkan bahwa Hydrilla verticillata dan Najas indica memiliki kemampuan meremediasi timbal $(\mathrm{Pb})$. Hydrilla verticillata memiliki ketahanan lebih baik dalam mengakumulasi timbal jika dibandingkan Najas indica, Hydrilla verticillata memliki kemampuan bertahan lebih lama dalam meremediasi timbal daripada Najas indica, sebaliknya Najas indica memiliki kemampuan meremediasi terhadap timbal $(\mathrm{Pb})$ lebih cepat daripada Hydrilla verticillata.
\end{abstract}

Kata kunci: fitoremediasi, timbal (Pb), Hydrilla verticillata, Najas indica.

\begin{abstract}
Phytoremediation is one of technique uses plants to reduce contaminant of lead (Pb) from the environment. Hydrilla verticillata and Najas indica is a Submerge plant water that are often found in South Sumatra. This research was conducted at the Integrated Research Laboratory Graduate School of Sriwijaya University. The research design used in this research is completely randomized design with factorial design of two factors, kinds of plants are Hydrilla verticillata and Najas indica, various concentration of $\mathrm{Pb}$ wich consisted control, $5 \mathrm{mg} / \mathrm{l}, 10 \mathrm{mg} / \mathrm{l}, 15 \mathrm{mg} / \mathrm{l}$. The measurement has 8 treatment and 3 replication for each treatment. Analysis Pb content in plants and in the water was measured on $5^{\text {th }}, 10^{\text {th }}, 15^{\text {th }}, 20^{\text {th }}$ with $A A S$ analysis method performed at a research laboratory in the Department of Chemistry, Faculty of Mathematics and Natural Science, Sriwijaya University. The obtained results from laboratory analysis was processed in Variant Analysis (ANOVA), if there was any significant difference, it would be continued by Duncan's New Multiple Range Test (DNMRT) at $5 \%$ level and calculation of absorbed speed of Hydrilla verticillata and Najas indica. Analysis of the data used 8.0 statistical software. The results showed that Hydrilla verticillata and Najas indica has the ability to remediate lead $(\mathrm{Pb})$ with $\mathrm{Pb}$ contents in plants was significantly different. Hydrilla verticillata has a better resistance in the accumulating lead $(P b)$ compared Najas indica. But Najas indica has a better absorption rate than Hydrilla verticillata.
\end{abstract}

Keywords: phytoremediation, lead (Pb), Hydrilla verticillata, Najas indica. 


\section{PENDAHULUAN}

Proses samping dari produksi dan kegiatan manusia yang dibuang ke perairan semakin meningkat seiring dengan perkembangan teknologi, pertanian, pertambangan dan lainlain sehingga air semakin tercemar. Salah satu bahan pencemar adalah 1 timbal $(\mathrm{Pb})$. Hasil penelitian Birmansyah (2008) menunjukkan tingginya kandungan $\mathrm{Pb}^{2+}$ didalam sedimen Sungai Musi sebesar $1,0191 \mu \mathrm{g} / \mathrm{g}-1,2442 \mu \mathrm{g} / \mathrm{g}$ yang disebabkan meningkatnya aktifitas industri dan transportasi dan sarana pelabuhan. Konsentrasi $\mathrm{Pb}$ yang mencapai $188 \mathrm{mg} / \mathrm{l}$ dapat membunuh ikan, dan jika $\mathrm{Pb}$ terlarut pada konsentrasi 2,75 - $49 \mathrm{mg} / \mathrm{l}$ dan terpapar selama 245 jam akan menyebabkan kematian pada Crustacea sedangkan pada konsentrasi $\mathrm{Pb}$ yang terlarut sebesar 3,5 - 64 $\mathrm{mg} / \mathrm{l}$ dan terpapar selama 168 - 336 jam akan menyebabkan kematian Insecta (Juhaeti et $a l$, 2005). Pengembangan alternatif yang efektif dan efisien diperlukan dengan semakin meluasnya kontaminasi perairan karena untuk merehabilitasi kasus kontaminan logam berat sehingga aman untuk kehidupan biota akuatik (Juhaeti et al, 2005).

Cemaran timbal $(\mathrm{Pb})$ di dalam air dapat direduksi dengan menggunakan tumbuhan air. Menurut Stowel et al (2000) tanaman air memiliki kemampuan secara umum dalam menetralisir komponen-komponen tertentu di dalam perairan sehingga sangat bermanfaat dalam proses pengolahan limbah cair. Hasil studi pendahuluan (tidak dipublikasikan) Hydrilla verticillata dan Najas indica banyak ditemukan di sekitar perairan danau Ski Air Jakabaring Palembang. Menurut Giesen \& Sukotjo (1991) bahwa Hydrilla verticillata dan Najas indica banyak dijumpai di danaudanau buatan maupun perairan di Sumatera Selatan.

Hydrilla verticillata dan Najas indica merupakan kelompok submerge aquatic plant yang telah diketahui mempunyai kemampuan mengakumulasi $\mathrm{Pb}$, tetapi belum banyak diketahui informasi mengenai pengaruh berbagai konsentrasi timbal $(\mathrm{Pb})$ terhadap kemampuan fitoremediasi dengan menggunakan Hydrilla verticillata dan
Najas indica. Penelitian ini bertujuan untuk: mengkaji kemampuan Hydrilla verticillata dan Najas indica dalam meremediasi cemaran timbal $(\mathrm{Pb})$ pada berbagai konsentrasi, mengkaji interaksi berbagai konsentrasi timbal $(\mathrm{Pb})$ terhadap kemampuan Hydrilla verticillata dan Najas indica dalam meremediasi cemaran logam berat $\mathrm{Pb}$.

\section{METODOLOGI PENELITIAN}

\section{Alat dan Bahan}

Bahan-bahan yang digunakan dalam penelitian ini adalah larutan stok standar $\mathrm{Pb}\left(\mathrm{NO}_{3}\right)_{2} 1000 \mathrm{pppm}$, Hydrilla verticillata, Najas indica, aquades, air $\mathrm{PAM}, \mathrm{HNO}_{3}$ pekat $65 \%$.

Alat-alat yang digunakan dalam penelitian ini adalah wadah plastik sebagai tempat media perlakuan, $\mathrm{pH}$ meter, AAS Shimatsu AA 7000, neraca analitik, erlenmeyer, kertas saring Whattman, pipet tetes, pipet volumetrik, hot plate, mortar, batang pengaduk, corong gelas, labu ukur, gelas ukur, oven, seperangkat alat saring vakum, botol sampel.

\section{Rancangan Penelitian}

Rancangan Penelitian yang digunakan pada penelitian ini adalah Rancangan Acak Lengkap (RAL) dengan pola faktorial dengan 2 faktor, yaitu macam jenis tanaman yaitu Najas indica dan Hydrilla verticillata, serta macam konsentrasi dengan 3 kali ulangan.

Faktor 1: Macam jenis tanaman dengan 2 taraf yaitu:

$\mathrm{A} 1=$ Hydrilla verticillata .

A2 = Najas indica

Faktor 2: variasi konsentrasi dengan 3 taraf yaitu,

B1 = Kontrol (tanpa perlakuan)

$\mathrm{B} 2=$ konsentrasi $5 \mathrm{mg} / \mathrm{l}$.

B3 = konsentrasi $10 \mathrm{mg} / \mathrm{l}$.

B4 = konsentrasi $15 \mathrm{mg} / \mathrm{l}$.

\section{Prosedur Kerja \\ Persiapan Fitoremediasi}

Tumbuhan yang dipilih mempunyai keseragaman kondisi yaitu: berasal dari tempat tumbuh yang sama, dengan kriteria panjang tumbuhan $10 \mathrm{~cm} \mathrm{~s} / \mathrm{d} 15 \mathrm{~cm}$, daun tumbuhan berwarna hijau segar. Media fitoremediasi yang digunakan berupa wadah 
plastik. Sampel tanaman Hydrilla verticillata dan Najas indica diambil dari Danau Sk Air Jakabaring Palembang selanjutnya dilakukan pencucian dari kotoran yang melekat dengan air bersih lalu diaklimatisasi selama lima hari.

\section{Perlakuan Fitoremediasi}

Hydrilla verticillata dan Najas indica masing-masing dengan berat basah 300 gr dimasukkan ke dalam wadah plastik berdiameter $90 \mathrm{~cm}$ dengan tinggi $30 \mathrm{~cm}$ yang telah berisi timbal sesuai dengan konsentrasi yang telah ditentukan kedalam $20 \mathrm{~L}$ air PAM. Larutan timbal diperoleh dari larutan standar stok $\mathrm{Pb}\left(\mathrm{NO}_{3}\right)_{2} 1000 \mathrm{ppm}$. Jumlah wadah plastik untuk fitoremediasi adalah 24 buah. Fitoremediasi yang dilakukan adalah fitoremediasi statis (air yang di-fitoremediasi dalam keadaan diam dan tidak bergerak) selama 20 hari dengan pengamatan pada hari ke 5, 10, 15 dan 20 .

\section{Proses Analisis Kandungan Logam berat timbal (Pb)}

Prosedur analisis kandungan logam berat timbal $(\mathrm{Pb})$ di dalam tumbuhan menggunakan acuan SNI 06-6992.3-2004 dan prosedur analisis logam berat timbal $(\mathrm{Pb})$ di dalam air berdasarkan prosedur SNI 6989.8.2009 menggunakan AAS.

\section{Variabel Pengamatan}

Pengukuran kadar timbal $(\mathrm{Pb})$ di dalam tanaman dan kadar timbal $(\mathrm{Pb})$ terlarut di dalam air dilakukan pada hari ke 5, 10, 15, 20.

\section{Analisa Data}

Data konsentrasi $\mathrm{Pb}$ di dalam Najas indica, Hydrilla verticillata dan data konsentrasi air di dalam perlakuan dilakukan Analisis Varian (ANAVA), jika berpengaruh nyata dilanjutkan dengan uji Duncans (DNMRT) pada taraf 5\%.

Perhitungan kecepatan absorpsi dalam penelitian ini didasarkan pada berdasarkan pada konsentrasi timbal $(\mathrm{Pb})$ awal dan konsentrasi timbal $(\mathrm{Pb})$ yang tertinggal yang diserap tumbuhan selama waktu pengamatan. Rumus yang digunakan adalah

$$
\text { Kecepatan penyerapan }=\frac{\mathrm{Pb} \text { awal didalam air }-\mathrm{Pb} \text { yang tersisa di air }}{\text { waktu }}
$$

\section{HASIL DAN PEMBAHASAN}

Kemampuan Hydrilla verticillata dan Najas indica dalam mennyerap timbal (Pb) di Danau Ski Air Jakabaring Palembang

Pengukuran kadar timbal $(\mathrm{Pb})$ dalam Hydrilla verticillata dan Najas indica sebelum perlakuan telah menunjukkan bahwa kedua jenis tanaman mempunyai kemampuan menyerap timbal $(\mathrm{Pb})$. Hasil Analisis Sidik Ragam menunjukkan sebelum perlakuan kadar $\mathrm{Pb}$ didalam tumbuhan berpengaruh nyata terhadap jenis tumbuhan (taraf $\alpha=5 \%$ ). Hasil uji lanjut Duncan yang di tampilkan pada tabel berikut ini:

Tabel 1. Rerata Kadar Pb didalam Hydrilla verticillata dan Najas indica di Danau Ski Air Jakabaring Palembang.

\begin{tabular}{cc}
\hline Jenis Tumbuhan & $\begin{array}{c}\text { Timbal }(\mathbf{P b}) \text { didalam } \\
\text { tumbuhan }(\mathbf{m g} / \mathbf{k g})\end{array}$ \\
Hydrilla & $8,38 \mathrm{a}^{1}$ \\
verticillata & $22,76 \mathrm{~b}^{2}$ \\
Najas indica &
\end{tabular}

Keterangan: Angka yang diikuti oleh huruf yang berbeda menunjukkan perbedaan yang nyata (significant different) pada uji lanjut DNMRT (Duncan New Multiple Range Test) taraf 5\%.

1. koordinat $3^{\circ} 1^{\prime} 22,52 \mathrm{LS}$ dan $104^{\circ} 47^{\prime} 5,00 \mathrm{BT}$

2 . koordinat $3^{\circ} 1^{\prime} 6,63 \mathrm{LS}$ dan $104^{\circ} 47^{\prime} 43,05 \mathrm{BT}$

Tabel 1 menunjukkan kadar $\mathrm{Pb}$ didalam Hydrilla verticillata berbeda nyata dengan kadar $\mathrm{Pb}$ didalam Najas indica. Perbedaan ini dapat disebabkan karena lokasi pengambilan tumbuhan dilakukan pada tempat yang berbeda sehingga memungkinkan distribusi timbal $(\mathrm{Pb})$ didalam perairan juga berbeda-beda walaupun masih dalam area yang sama yaitu stadion gelora sriwijaya jakabaring Palembang. Soeprobowati (2011) melaporkan wilayah Asinan dan wilayah Dangkel yang merupakan satu wilayah Danau Rawapening timbal $(\mathrm{Pb})$ memiliki kandungan timbal di dalam air sebesar 0,155 $\mathrm{mg} / \mathrm{l}$ dan 0,315 mg/l (Soeprobowati, 2011). Hasil penelitian Xing et al (2013) menunjukkan terdapat perbedaan kadar logam berat $\mathrm{Al}, \mathrm{Ba}, \mathrm{Ca}, \mathrm{K}, \mathrm{Li}, \mathrm{Mg}, \mathrm{Na}, \mathrm{Se}$, $\mathrm{Sr}$ dan $\mathrm{Ti}$ di dalam jaringan Hydrilla verticillta sebesar $5.000 \mathrm{mg} / \mathrm{kg}-8.000$ $\mathrm{mg} / \mathrm{kg}$ dan Najas marina sebesar $5 \mathrm{mg} / \mathrm{kg}$ - 
$15.000 \mathrm{mg} / \mathrm{kg}$ pada 24 danau eutrofik di sepanjang aliran sungai Yangtse Cina.

Pengambilan tumbuhan uji ini dilakukan pada akhir bulan Februari 2015, dimana bulan tersebut adalah musim hujan. Maiti \& Shishir (2008) menyatakan akumulasi Pb di dalam tumbuhan air meningkat pada musim hujan. Kadar $\mathrm{Pb}$ di dalam tumbuhan masih dalam batas normal sebesar $0,2-20 \mathrm{mg} / \mathrm{kg}$. Dapat disimpulkan secara alami Hydrilla verticillata dan Najas indica mampu mengakumulasi $\mathrm{Pb}$.

Kemampuan Hydrilla verticillata dan Najas indica dalam meremediasi timbal (Pb).
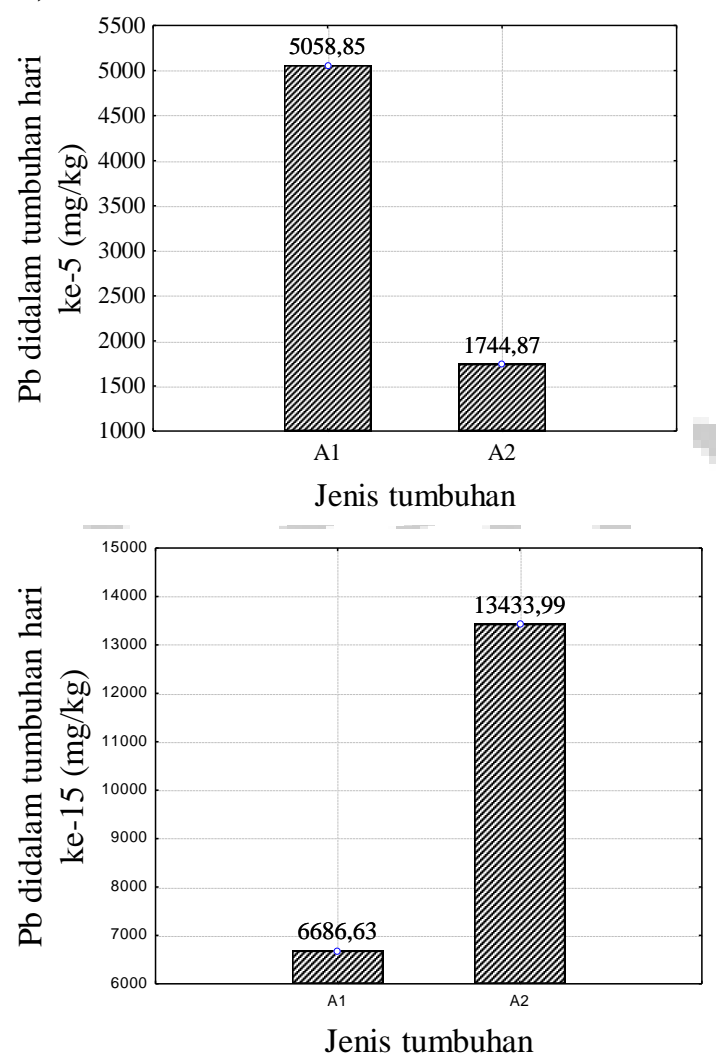

Hydrilla verticillata dan Najas indica merupakan salah satu tumbuhan air yang banyak ditemukan di Sumatera Selatan telah terbukti mampu meremediasi timbal. Hasil Analisis Sidik Ragam menunjukkan pada hari ke 5, 10, 15 setelah diberi perlakuan, kadar $\mathrm{Pb}$ didalam tumbuhan berpengaruh nyata terhadap jenis tumbuhan (taraf $\alpha=$ $5 \%$ ). Sedangkan pada hari ke 20 jenis tumbuhan tidak berpengaruh nyata. Hasil uji lanjut Duncan menunjukkan Hydrilla verticillata berbeda nyata dengan Najas indica. Kemampuan Hydrilla verticillata dan Najas indica dalam menyerap timbal ditampilkan pada gambar berikut.
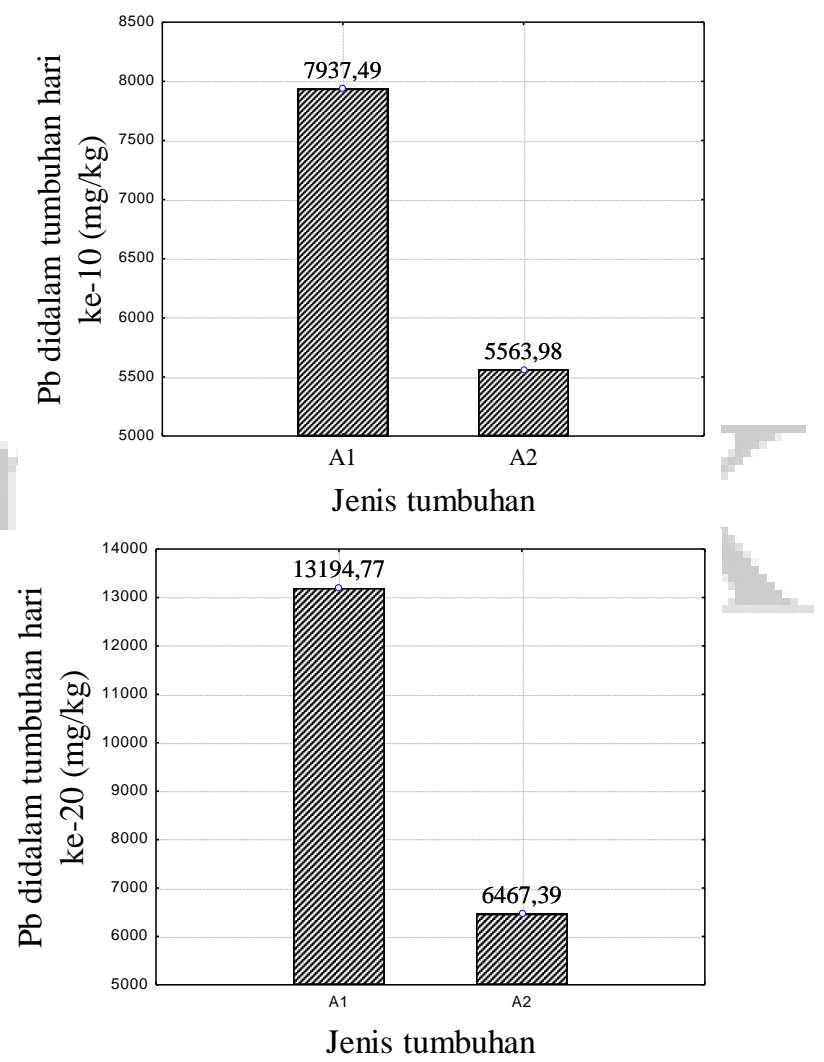

Gambar 1. Pengaruh jenis tumbuhan dalam meremediasi timbal (Pb)

Gambar 1 menunjukkan bahwa perlakuan pada hari ke 5 sampai dengan hari ke 20 , Hydrilla verticillata mampu mengakumulasi timbal berkisar 5.058,85 $-13.194,77 \mathrm{mg} / \mathrm{kg}$ sedangkan Najas indica mampu mengakumulasi timbal sebesar 1.744,87 $13.433,99 \mathrm{mg} / \mathrm{kg}$. Hydrilla verticillata mampu meremediasi timbal lebih banyak jika dibandingkan dengan Najas indica pada hari ke 5 dan ke 10. Sebaliknya Najas indica mampu meremediasi timbal lebih banyak dibandingkan Hydrilla verticillata pada hari ke 15. Kemampuan Hydrilla verticillata kembali meningkat pada hari ke 20. Menurut Hidayati (2013) bahwa perbedaan dari serangkaian proses fisiologis biokimia dan serangkaian ekspresi gen-gen yang berperan dalam proses penyerapan, akumulasi dan toleransi tanaman terhadap logam mengakibatkan adanya perbedaan yang besar dalam kemampuan meremediasi dan mentolerir logam pada tumbuhan. Hasil 
penelitian Xing et al (2013) menunjukkan bahwa tumbuhan air submerged memiliki luas permukaan lebih besar untuk kontak dengan air jika dibandingkan dengan tumbuhan air non submerged sehingga kadar logam berat di dalam tumbuhan air bisa lebih dari 100.000 kali lebih besar dari kadar logam berat di dalam air.

\section{Pengaruh konsentrasi terhadap} kemampuan Hydrilla verticillata dan Najas indica dalam meremediasi timbal $(\mathbf{P b})$.

Berdasarkan penelitian yang telah dilakukan menunjukkan konsentrasi berpengaruh terhadap kemampuan Hydrilla verticillata dan Najas indica dalam meremediasi timbal. Marthana et al (2014) menyatakan kemampuan Hydrilla verticillata berkorelasi positif dengan kadar logam berat di dalam sedimen. Sebaliknya hasil penelitian Xing et
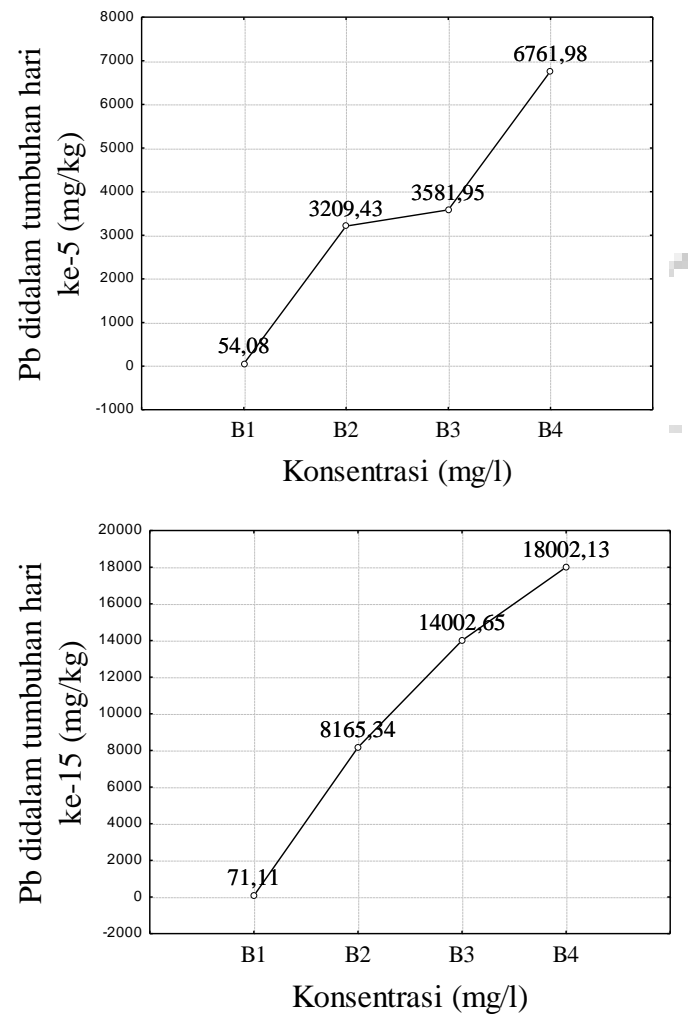

al (2013) bahwa kadar logam berat di dalam jaringan Hydrilla verticillata dan Najas marina berkorelasi positif dengan kadar logam berat di dalam air. Hasil Analisis Sidik Ragam menunjukkan bahwa konsentrasi timbal pada hari ke 5, 10, 15 dan 20 setelah diberi perlakuan berpengaruh nyata terhadap kadar $\mathrm{Pb}$ didalam tumbuhan (taraf $\alpha=5 \%$ ). Hasil uji lanjut Duncan (lampiran 3) didapatkan pada hari ke 5, 10 dan 20 masing-masing perlakuan yaitu B2, B3, dan B4 berbeda nyata jika dibandingkan dengan kontrol (B1). Tetapi pada hari ke 5 antara perlakuan B2 dan B3 berbeda tidak nyata dan pada hari ke 15 antara perlakuan B3 dan B4 berbeda tidak nyata. Pengaruh konsentrasi timbal terhadap kemampuan Hydrilla verticillata dan Najas indica dalam meremediasi timbal ditampilkan pada Gambar 2 berikut:
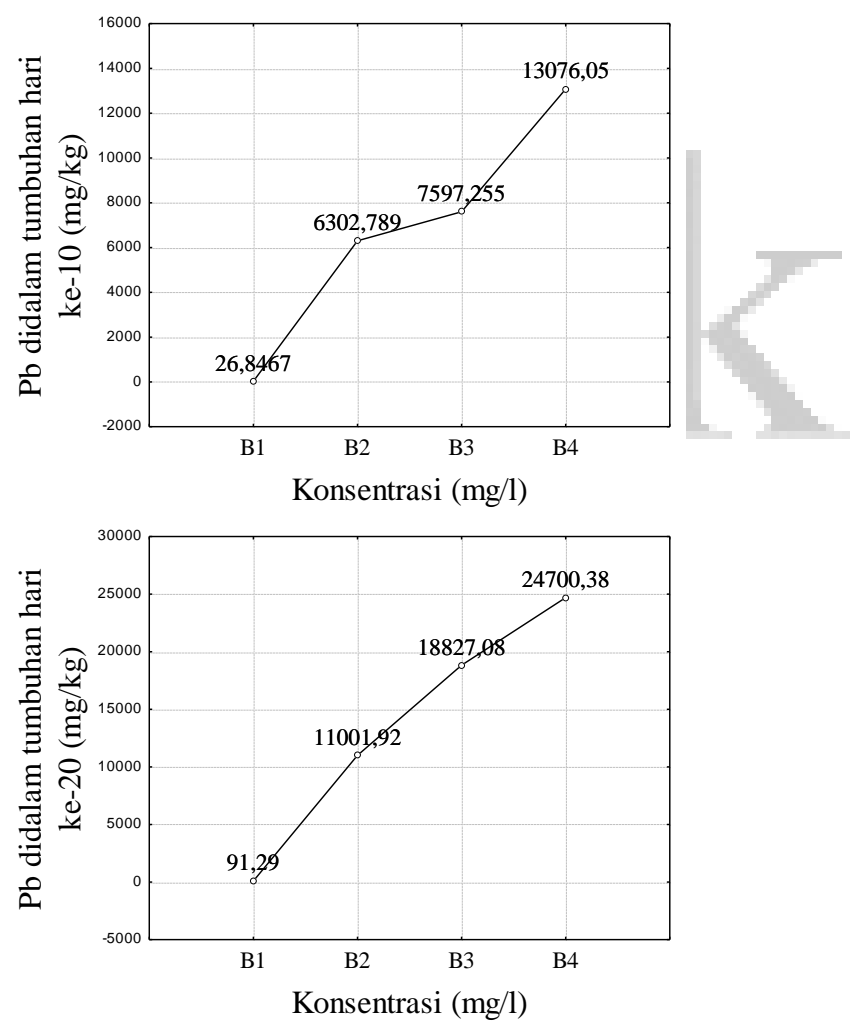

\section{Gambar 2. Pengaruh Konsentrasi terhadap kemampuan Hydrilla verticillata dan Najas indica dalam meremediasi timbal}

Gambar 2 menunjukkan bahwa semakin tinggi konsentrasi timbal di dalam air maka semakin tinggi $\mathrm{Pb}$ yang diserap oleh Hydrilla verticillata dan Najas indica. Menurut Malik \& Biswas (2012) bahwa setiap tumbuhan memiliki kemampuan yang berbeda-beda dalam menyerap logam berat tergantung dari konsentrasi logam didalam media tersebut. Selain itu juga bahwa perbedaan kandungan $\mathrm{Pb}$ antara media tanaman menyebabkan semakin besar pula logam $\mathrm{Pb}$ yang diserap oleh tumbuhan 
dimana perbedaan kandungan ini akan menyebabkan terjadinya perpindahan logam $\mathrm{Pb}$ secara difusi dan osmosis yaitu massa zat pada media dengan kandungan yang tinggi akan berpindah ke media dengan kandungan yang rendah (Haryati et al, 2012). Dengan adanya perpindahan kandungan maka akan terjadi penyerapan $\mathrm{Pb}$ oleh tanaman. Inilah yang merupakan prinsip penyerapan logam $\mathrm{Pb}$ oleh tumbuhan dimana semakin besar kandungan $\mathrm{Pb}$ dalam media maka akan menyebabkan semakin besar pula logam $\mathrm{Pb}$ yang diserap oleh tanaman (Ghosh \& Singh, 2005). Hydrilla verticillata mempunyai kemampuan meremediasi timbal $15 \mathrm{mg} / \mathrm{l}$ sampai hari ke 20. Proklamasiningsih \& Hemayanti (2008) menyatakan bahwa pemberian timbal sampai dengan $15 \mathrm{mg} / \mathrm{l}$ masih dapat ditoleransi oleh Hydrilla verticillata. Sebaliknya Najas indica mempunyai kemampuan meremediasi timbal $5 \mathrm{mg} / \mathrm{l} \mathrm{sampai}$ hari ke 15 . Perlakuan $10 \mathrm{mg} / \mathrm{l}$ dan $15 \mathrm{mg} / \mathrm{l}$ mengakibatkan kematian Najas indica pada hari ke 20. Ini menujukkan penggunaan Najas indica sebagai agen fitoremediasi di air dapat dilakukan jika konsentrasi timbal $<5 \mathrm{mg} / \mathrm{l}$.
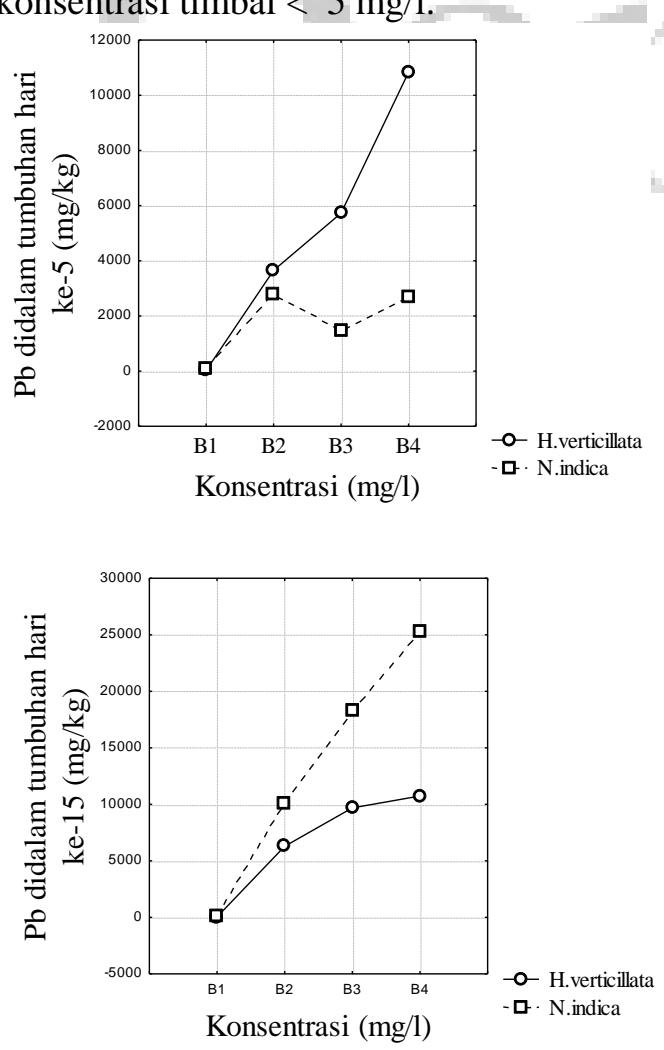

\section{Interaksi Hydrilla verticillata dan Najas indica dan konsentrasi dalam meremediasi timbal $(\mathbf{P b})$.}

Berdasarkan penelitian menunjukkan Hydrilla verticillata dan Najas indica mampu meremediasi timbal pada berbagai konsentrasi. Hasil penelitian ini didapatkan adanya interaksi jenis tumbuhan dan konsentrasi berpengaruh nyata. Hasil Analisis Sidik Ragam) pada hari ke 5, 10, 15 dan 20 (taraf $\alpha=5 \%$ ). Hasil uji lanjut Duncan menunjukkan pada hari ke 5 dan 10 dan 15, A1B2 dengan A2B2 berbeda tidak nyata, A1B3 dengan A2B3 dan A1B4 dengan A2B4 berbeda nyata jika dibandingkan dengan kontrol (B1), sedangkan pada hari ke 20 tidak dapat dilakukan uji lanjut karena tidak terdapat interaksi antara jenis tumbuhan dengan konsentrasi. Hal ini disebabkan Najas indica telah mengalami kematian pada konsentrasi B3 dan B4. Interaksi Hydrilla verticillata dan Najas indica dan konsentrasi dalam meremediasi timbal $(\mathrm{Pb})$ ditampilkan pada Gambar 3.
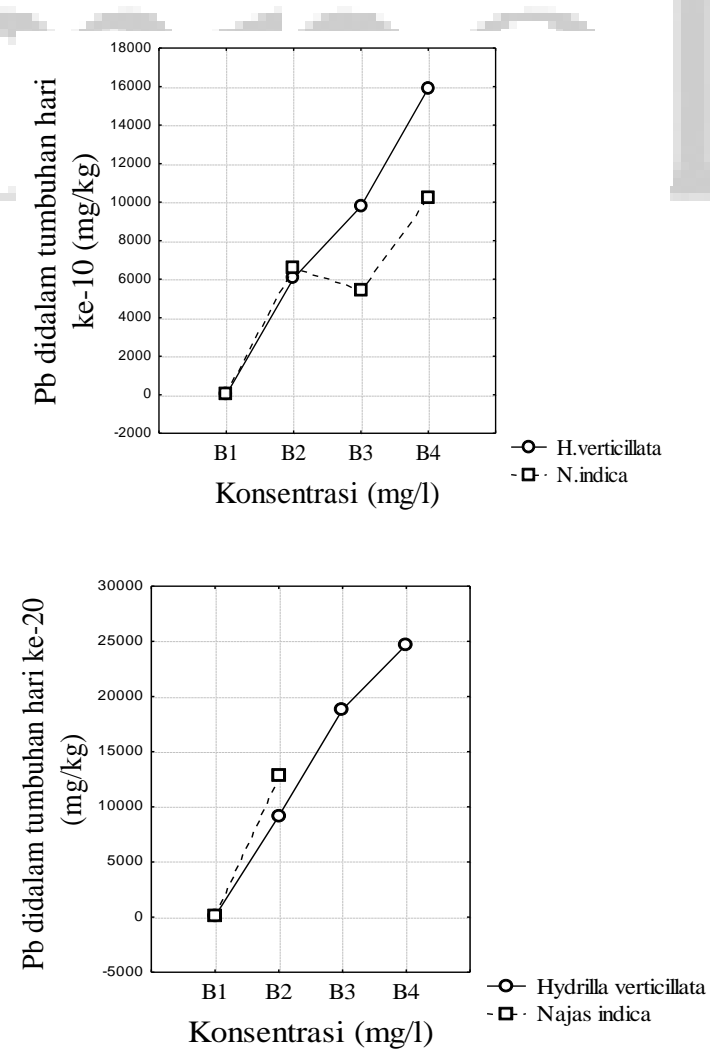

Gambar 3. Interaksi kemampuan Hydrilla verticillata dan Najas indica terhadap konsentrasi dalam meremediasi timbal (Pb) 
Gambar 3 menunjukkan kemampuan Hydrilla verticillata dan Najas indica dipengaruhi oleh konsentrasi, dengan batas toleransi konsentrasi timbal pada Hydrilla verticillata dan Najas indica berbeda. Kemampuan Hydrilla verticillata melebihi Najas indica dengan konsentrasi B2, B3 dan B4 pada hari ke 5. Sebaliknya kemampuan Najas indica melebihi Hydrilla verticillata pada hari ke 15. Srivasta et al (2008) melaporkan tumbuhan submerge memiliki kemampuan dalam mengurangi konsentrasi logam berat di dalam air dengan menyerap logam berat dalam jumlah yang besar. Penelitian Xing et al (2013) bahwa terdapat korelasi positif antara kadar logam didalam jaringan Hydrilla verticillata dan Najas marina dengan konsentrasi logam di 24 danau eutrofik di Cina. Srivastava et al (2008) melaporkan bahwa Najas guadalupensis mempunyai kemampuan mendetoksifikasi metabolit beracun, sehingga hal ini dapat digunakan untuk menjernihkan air. Berdasarkan hasil wawancara dengan pihak pengelola Danau

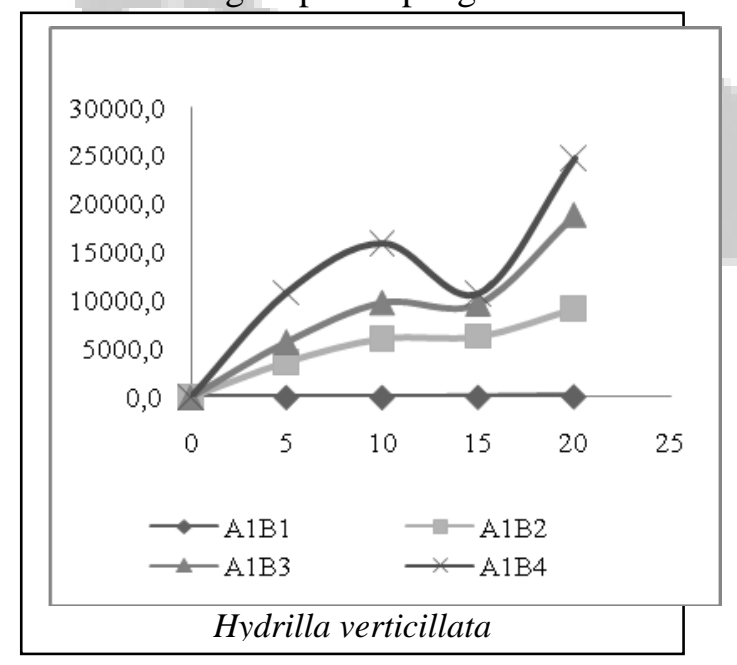

Ski Air Jakabaring Palembang, Najas indica sengaja dimasukkan ke dalam Danau Ski Air Palembang untuk menjernihkan air di danau tersebut yang sebelumnya berwarna coklat akibat masukan air dari berbagai aliran sungai disekitar danau. Kemampuan tanaman air untuk menyaring bahan-bahan yang larut di dalam limbah cair potensial untuk dijadikan bagian dari pengolahan limbah cair. Terjadi proses penyaringan dan penyerapan oleh akar dan batang tanaman air, proses pertukaran dan penyerapan ion pada proses pengolahan limbah cair di dalam suatu perairan yang meggunakan tumbuhan air (Yusuf, 2008).

Percobaan ini bertujuan untuk mengkaji pengaruh waktu terhadap kemampuan Hydrilla verticillata dan Najas indica dalam mengakumulasi timbal $(\mathrm{Pb})$ pada berbagai konsentrasi. Percobaan dilakukan dengan cara buatan yaitu membuat lingkungan air terpapar timbal $(\mathrm{Pb})$. Hasil penelitian disajikan pada Gambar 4.

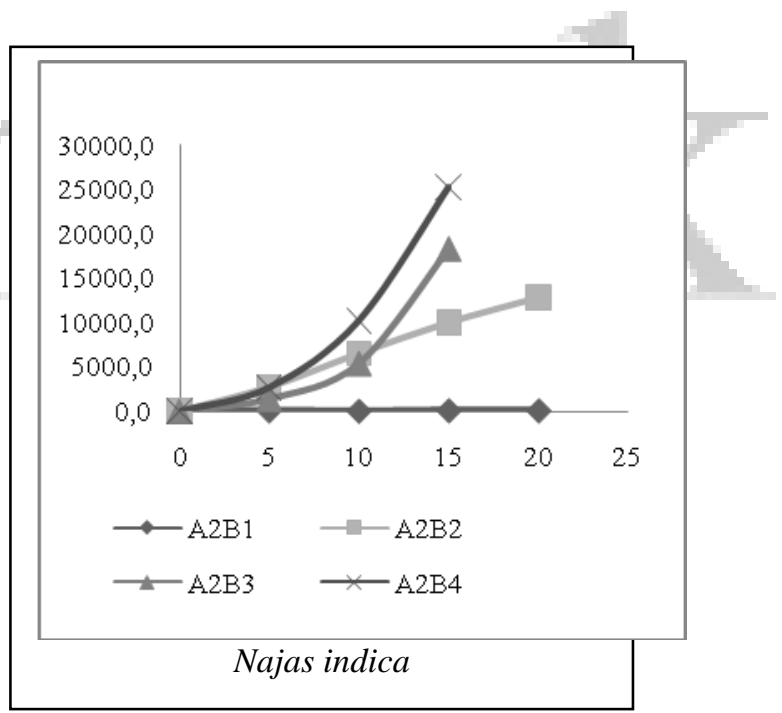

Gambar 4. Pengaruh waktu terhadap kemampuan Hydrilla verticillata dan Najas indica dalam meremediasi timbal

Gambar 4 menunjukkan bahwa Hydrilla verticillata mampu bertahan hidup terhadap lingkungan yang terpapar $\mathrm{Pb}$ pada konsentrasi $\mathrm{Pb} 15 \mathrm{mg} / \mathrm{l}$ sampai dengan hari ke-20. Pada kondisi tersebut kemampuan Hydrilla verticillata menyerap logam $\mathrm{Pb}$ yang terserap sebesar 3.653 - 24.700,4 $\mathrm{mg} / \mathrm{kg}$. Kemampuan Hydrilla verticillata dalam menyerap $\mathrm{Pb}$ menunjukkan peningkatan seiring dengan tingginya konsentrasi $\mathrm{Pb}$ didalam air dan waktu kontak. Hydrilla verticillata mengeluarkan strategi pertahanannya pada hari ke 5 dan ke 10 dengan cara metal indicator, dimana Hydrilla verticillata mentoleransi keberadaan konsentrasi logam dengan menghasilkan senyawa pengikat logam atau mengubah susunan logam dengan menyimpan logam pada bagian yang tidak sensitif. Sebaliknya Hydrilla verticillata pada hari ke 15 mengalami penurunan penyerapan dan kembali meningkat pada hari ke 20. Hal ini dapat terjadi dikarenakan pada titik tertentu tumbuhan akan 
mengalami kejenuhan. Kejenuhan tersebut diduga karena pada hari sebelumnya Hydrilla verticillata telah menyerap semua zat-zat yang berada dalam media, sehingga pada hari ke 15 zat-zat yang telah terserap menumpuk dalam jaringan tumbuhan yang mngakibatkan terhambatnya penyerapan. Selain itu juga pada hari ke 15 Hydrilla verticillata mekanisme pertahanan yang disebut sebagai metal excluder, dimana Hydrilla verticillata mencegah masuknya logam dari bagian aerial atau menjaga agar konsentrasi logam tetap rendah dalam air (Lambers et al, 2010).

Lamanya perlakuan menunjukkan tumbuhan mempunyai kontak optimum untuk menyerap logam berat $\mathrm{Pb}$ secara maksimal. Hydrilla verticillata mengalami penurunan dalam meremediasi timbal diduga karena terjadi proses desorpsi. Hal ini merupakan salah satu fenomena dalam adsorpsi fisika yang menyatakan bahwa proses adsorpsi bersifat reversibel (Lelifajri, 2010). Menurut Widaningrum et al (2007) bahwa waktu kontak sangat mempengaruhi daya serap. Semakin lama waktu kontak maka penyerapan juga akan meningkat sampai pada waktu tertentu akan mencapai maksimum dan setelah itu akan turun kembali. Gambar 4 menunjukkan kurva kadar timbal $(\mathrm{Pb})$ di dalam Hydrilla verticillata berbentuk linier dimana waktu kontak optimum untuk Hydrilla verticillata diperoleh pada hari ke-20. Hydrilla verticillata melakukan mekanisme pertahanan tubuh dengan cara metal accumulator pada hari ke 20, dimana Hydrilla verticillata mengkonsentrat konsentrasi logam yang tinggi pada bagian aerial tumbuhan, dan menyerap kadar kontaminan yang tinggi dan diendapkan dalam akar, batang, daun atau tunas. (Lambers, 2010). Oleh karena itu pada hari ke 20 Hydrilla verticillata kembali mengalami peningkatan dalam mengakumulasi timbal.

Najas indica mampu hidup pada konsentrasi $5 \mathrm{mg} / \mathrm{l}$ sampai dengan hari ke 20,dan mengalami kematian pada hari ke 20 dengan konsentrasi 10 dan $15 \mathrm{mg} / \mathrm{l}$. Pada kondisi tersebut kemampuan menyerap logam $\mathrm{Pb}$ sebesar $2.691-25.267,2 \mathrm{mg} / \mathrm{kg}$ pada konsentrasi 5 mg/l - 15 mg/l. Waktu kontak optimum Najas indica diperoleh pada hari ke 15. Ini menunjukkan pada hari ke 15 Najas indica mampu menyerap timbal $(\mathrm{Pb})$ secara maksimal.

Jika dibandingkan dapat dilihat bahwa Hydrilla verticillata dan Najas indica memiliki kemampuan yang besar dalam meremediasi timbal $(\mathrm{Pb})$. Hal ini ditunjukkan pada kemampuan menyerap Hydrilla verticillata pada konsentrasi 15 $\mathrm{mg} / \mathrm{l}$ mencapai 24.700,4 $\mathrm{mg} / \mathrm{kg}$ pada konsentrasi $15 \mathrm{mg} / \mathrm{l}$ pada hari ke 20. Najas indica mampu menyerap $\mathrm{Pb}$ mencapai $25.267,2 \mathrm{mg} / \mathrm{kg}$ pada hari ke 15. Hydrilla verticillata mempunyai luas permukaan yang lebih besar jika dibandingkan Najas indica sehingga kontak dengan logam $\mathrm{Pb}$ semakin besar. Menurut Henggar (2009) bahwa tumbuhan yang memiliki ukuran lebih besar lebih baik dalam mengolah kontaminan. Malik \& Biswas (2012) bahwa Hydrilla verticillata merupakan tumbuhan hiperakumulator. Sebaliknya Najas indica mempunyai luas permukaan daun yang lebih kecil daripada Hydrilla verticillata tetapi memiliki daun yang banyak sehingga penyerapan lebih banyak memungkinkan sampai ke pucuk. Malik \& Biswas (2012) menyatakan kemampuan menyerap lebih dari $0,1 \% \mathrm{~Pb}$ dari berat kering pada daun. Dari kemampuan waktu kontak optimum menunjukkan Najas indica lebih cepat menyerap timbal $(\mathrm{Pb})$ daripada Hydrilla verticillata.

\section{Kecepatan Penyerapan Hydrilla verticillata dan Najas indica dalam meremediasi $\mathbf{P b}$ di dalam air.}

Pada penelitian ini dilakukan pengukuran kadar $\mathrm{Pb}$ di dalam air untuk mengukur kecepatan penyerapan dan memastikan bahwa timbal telah terserap oleh di dalam Hydrilla verticillata dan Najas indica. Hasil Analisis Sidik Ragam menunjukkan jenis tumbuhan, konsentrasi dan interaksi jenis tumbuhan dengan konsentrasi berpengaruh nyata terhadap kadar $\mathrm{Pb}$ di dalam air pada hari ke 5, 10, 15. Sedangkan pada hari ke 20 hanya jenis tumbuhan, konsentrasi yang berpengaruh nyata terhadap kadar $\mathrm{Pb}$ di dalam air. Hasil uji lanjut Duncan menunjukkan kadar timbal di dalam media Hydrilla verticillata berbeda nyata dengan kadar timbal di dalam media Najas indica. Kadar timbal di dalam air ditunjukkan pada 
uji lanjut pengukuran kadar $\mathrm{Pb}$ terlarut didalam air dan kadar $\mathrm{Pb}$ didalam tumbuhan
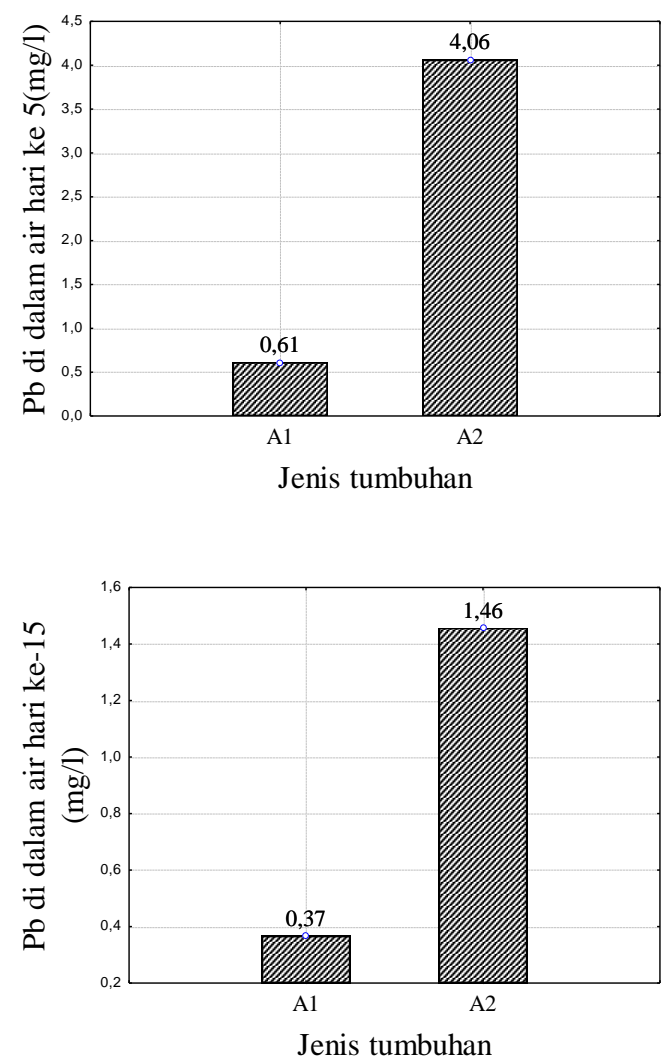

pada hari ke 5, 10, 15 dan 20 ditampilkan pada Gambar 5 berikut.
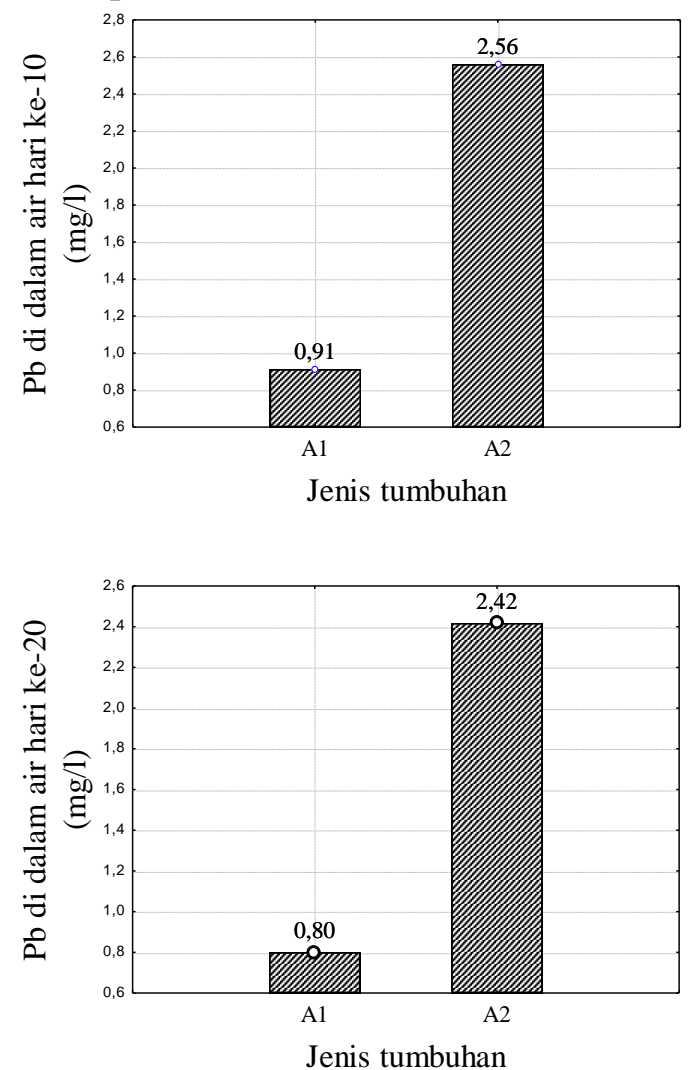

Gambar 5. Kemampuan penyerapan Hydrilla verticillata (A1) dan Najas indica (A2)

Gambar 5 menunjukkan bahwa setelah perlakuan kadar $\mathrm{Pb}$ yang tersisa pada air media Hydrilla verticillata berkisar 0,37 $0,91 \mathrm{mg} / \mathrm{l}$ sedangkan pada media Najas indica kadar $\mathrm{Pb}$ yang tersisa di air sebesar $1,46-4,06 \mathrm{mg} / \mathrm{l}$. Hal ini menunjukkan kedua jenis tumbuhan ini mampu meremediasi timbal di dalam air.

Hasil Analisis Sidik Ragam menunjukkan bahwa konsentrasi timbal pada hari ke 5, 10, 15 dan 20 berpengaruh terhadap kadar $\mathrm{Pb}$ yang tersisa di dalam air (taraf $\alpha=5 \%$ ). Hasil uji lanjut Duncan menunjukkan pada hari ke 5 perlakuan B2, B3 dan B4 berbeda nyata terhadap kontrol (B1). Pada hari ke 10 dan 15 perlakuan $\mathrm{B} 2$ berbeda tidak nyata jika dibandingkan B1, dan perlakuan B2 berbeda nyata dengan B3 dan B4. Pada hari ke 20 perlakuan B2 berbeda tidak nyata dengan $\mathrm{B} 1$, perlakuan $\mathrm{B} 2$ berbeda tidak nyata dengan $\mathrm{B} 3$, perlakuan $\mathrm{B} 4$ berbeda nyata dengan perlakuan $\mathrm{B} 2$ dan $\mathrm{B} 3$.
Interaksi Hydrilla verticillata dan Najas indica dan konsentrasi berpengaruh nyata terhadap kadar $\mathrm{Pb}$ yang tersisa di dalam air pada hari ke $5-15$, sedangkan pada hari ke 20 tidak berpengaruh nyata (taraf $\alpha=5 \%$ ). Hasil uji lanjut Duncan menunjukkan antara A1B2 dengan A2B2, A1B3 dengan A2B3, dan A1B4 dengan A2B4 pada hari ke 5 berbeda nyata jika dibandingkan dengan kontrol (A1B1) dan (A2B2). Perlakuan A1B2 dengan A2B2 berbeda tidak nyata, A1B3 dengan A2B3 berbeda nyata, dan A1B4 dengan A2B4 berbeda nyata pada hari ke 10 jika dibandingkan dengan kontrol (A1B1) dan (A2B2). Perlakuan A1B2 dengan A2B2 berbeda nyata, A1B3 dengan A2B3 berbeda nyata, dan A1B4 dengan A2B 4 berbeda nyata jika dibandingkan dengan kontrol (A1B1 dan A2B2) pada hari ke 15. Perbandingan kemampuan Hydrilla verticillata dan Najas indica dalam meremediasi timbal ditampilkan pada Gambar 6. 

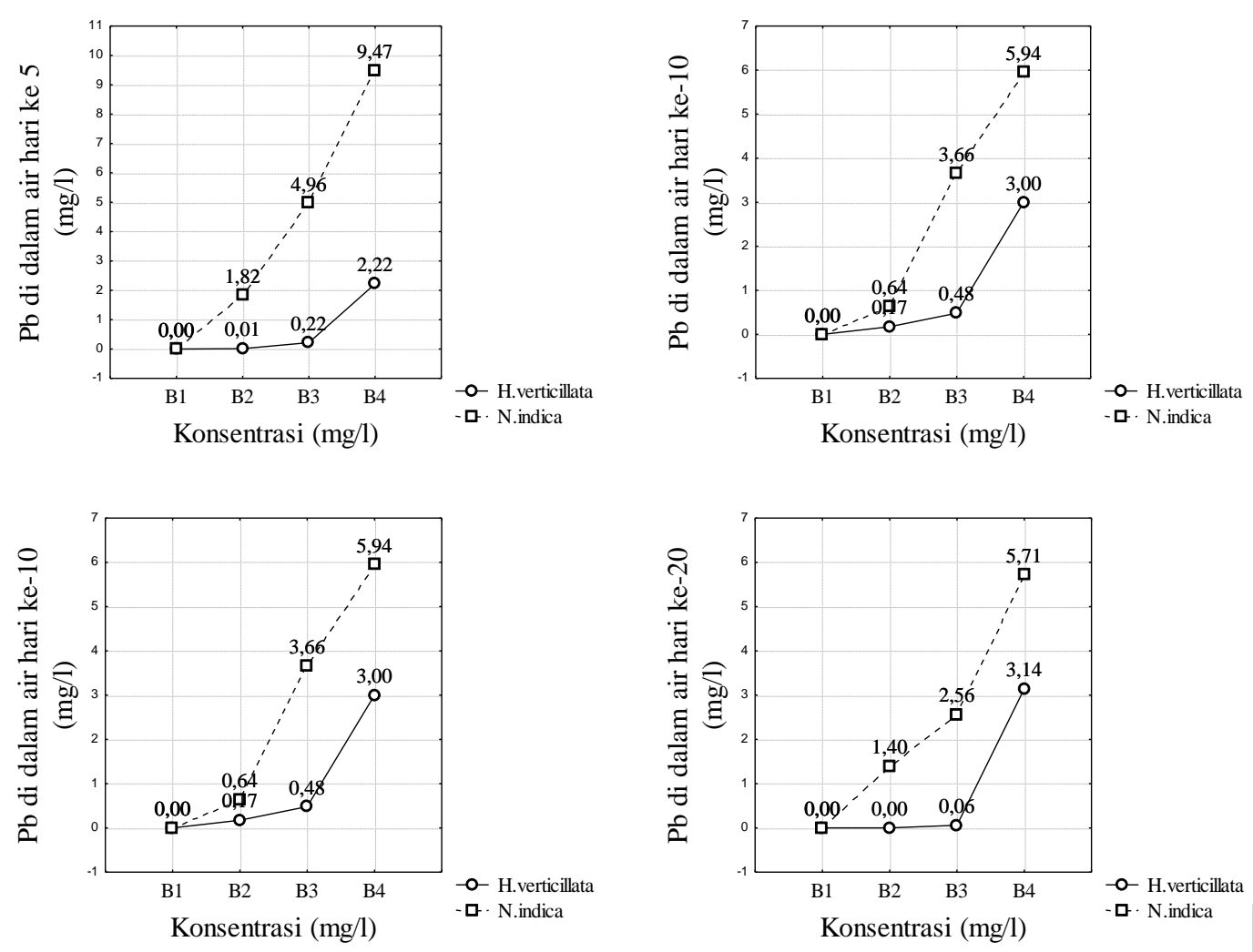

\section{Gambar 6 Perbandingan kemampuan Hydrilla verticillata dan Najas indica dalam meremediasi timbal}

Gambar 6 , kadar $\mathrm{Pb}$ yang tersisa pada media Hydrilla verticillata dan Najas indica telah mengalami penurunan dari konsentrasi awal perlakuan, hal ini menunjukkan Hydrilla verticillata dan Najas indica dengan biomassa 300 gr berat basah mampu meremediasi timbal dengan konsentrasi mulai 5mg/l sampai dengan hari ke 20 . Setiap tumbuhan memiliki kemampuan yang berbeda-beda dalam menyerap logam berat. Salah satu faktor yang mempengaruhi penyerapan logam berat oleh tumbuhan adalah biomassa. Salvinia molesta dengan berat 60 gr berat basah mampu menurunkan $\mathrm{Pb}$ dari $0,8 \mathrm{mg} / \mathrm{l}$ menjadi $0,304 \mathrm{mg} / \mathrm{l}$ sampai hari ke 12 (Viobeth et al, 2013).

Kadar $\mathrm{Pb}$ di dalam air media Hydrilla verticillata bersifat fluktuatif, terutama pada hari ke 10, kadar $\mathrm{Pb}$ didalam air nilainya lebih besar jika dibandingkan pada hari ke 5 . Hal ini diduga karena tumbuhan uji ada yang mulai tumbuh dan ada yang mulai mati, sehingga penyerapan tidak maksimal. Menurut Lakitan (2004) bahwa logam berat dapat mempengaruhi tumbuhan dengan cara menghambat enzim sehingga protein akan mengalami denaturasi yang dapat memutuskan ikatan hidrogen. Kadar $\mathrm{Pb}$ didalam Hydrilla verticillata dan Najas indica juga dapat disebabkan karena membran sel telah rusak sehingga ion-ion logam berat $\mathrm{Pb}$ keluar dari sitosol. Pada penelitian ini media ditempatkan pada tempat terbuka langsung terkena cahaya matahari. Menurut Lakitan (2004) bahwa ion-ion yang diangkut masuk ke dalam vacuola sel akan jarang yang diangkut kembali ke luar dari vacuola tersebut. Kebocoran membran (ion keluar dari sitosol) akan berlangsung mudah jika membran tersebut telah rusak misalnya akibat suhu tinggi atau penyebab lainnya. Selain itu juga pada beberapa spesies, akar dan tajuknya dapat mengandung jumlah yang lebih tinggi jika dibandingkan spesies lain. Hal ini dapat disebabkan secara genetis tumbuhan memiliki kemampuan yang sangat beragam untuk toleran atau tidak toleran terhadap 
unsur tak esensial seperti logam berat $\mathrm{Pb}$ (Salisbury \& Ross, 1995).

Hydrilla verticillata dan Najas indica merupakan kedua jenis tumbuhan yang submerge. Dari penelitian yang telah dilakukan menunjukkan kedua jenis tumbuhan ini mampu mengakumulasi logam $\mathrm{Pb}$. Mekanisme kedua jenis tumbuhan ini dapat dilakukan dengan beberapa cara. Yang pertama yaitu dengan pertukaran kation. Kation masuk ke dalam sel - sel akar secara pasif, sedangkan anion diangkut secara aktif ke dalam sel akar tumbuhan (Lambers et al, 2010). Dimana kation sel - sel akar tumbuhan mengandung ion dengan konsentrasi yang lebih tinggi dari pada media sekitarnya yang biasanya bermuatan negatif. Apabila ion di sekitar sel-sel akar bermuatan positif (kation), penyerapan logam berat $\mathrm{Pb}$ tidak membutuhkan energi. Yang kedua adalah akar tumbuhan air seperti yang mengalami stres logam berat akan membentuk zat phytochelatin dan metalothionin (Maiti et al, 2004 ). Phytochelatin adalah kelompok protein yang memiliki asam amino cystein, glycin dan asam glutamat, yang menginduksi tanaman jika tanaman mengalami stres logam berat. Atom belerang dalam sistein ini yang akan mengikat logam berat dari media tumbuh. Senyawa ini mengikat ion logam dan membawanya ke vakuola dimana logam berat tidak menjadi toksik (Suresh \& Ravinkar, 2004). Spesies tumbuhan yang tumbuh di lingkungan tercemar logam akan mengalami stres logam dengan membentuk zat phytochelatin khususnya di bagian akar sebagai mekanisme toleransi yang penting (Lambers et al, 2010). Metallothionein merupakan zat yang menciptakan lokasi penyimpanan ion untuk kelebihan ion - ion logam berat bebas yang dikhelasi. Metallothionin adalah protein transport yang bertanggung jawab pada pemindahan kelebihan logam berat dari satu tempat ke tempat yang lain untuk menghindari efek toksik yang ditimbulkan terhadap tanaman (Shuresh \& Ravinskar, 2004). Phytochelatin dan metallothionin bekerjasama dalam mengikat logam berat $\mathrm{Pb}$ yang ada di dalam air. Setelah phytochelatin mengikat logam berat $\mathrm{Pb}$ maka zat methallothienein akan menempatkan logam berat $\mathrm{Pb}$ ke suatu sel atau jaringan dalam hal ini akar untuk menyimpan logam berat $\mathrm{Pb}$, sehingga keberadaan logam $\mathrm{Pb}$ tidak akan mengganggu metabolisme tumbuhan, terutama tumbuhan Hydrilla verticillata. Cara ketiga proses rhizofiltrasi yaitu adsorbsi atau absorpsi logam oleh akar tanaman (Malik dan Biswas, 2012). Dalam akumulasi logam berat oleh tumbuhan, logam harus dibawa ke dalam larutan di sekitar akar (rizosfer) agar terjadi penyerapan oleh akar. Dimana senyawa senyawa yang larut dalam air akan diambil oleh akar bersama air, dan senyawa senyawa hidrofobik diserap oleh permukaan akar. Selain itu juga translokasi logam dari akar ke bagian tanaman lain merupakan proses akumulasi logam berat oleh tumbuhan dimana setelah logam menembus endodermis akar, logam berat akan mengikuti aliran transpirasi ke bagian atas tanaman melalui jaringan pengangkut ke bagian tanaman lainnya. Agar logam tidak menghambat metabolisme tanaman terjadi lokalisasi logam pada sel dan jaringan. Ini menunjukkan tumbuhan mempunyai mekanisme detoksifikasi dengan menimbun logam di dalam organ tertentu seperti akar sebagai bentuk pertahanan keracunan terhadap sel (Suresh dan Ravinskar, 2004).

Kemampuan Hydrilla verticillata dan Najas indica dalam menyerap timbal $(\mathrm{Pb})$ dapat dilihat dari kecepatan penyerapan kedua jenis tumbuhan ini. Hasil perhitungan kecepatan penyerapan timbal $(\mathrm{Pb})$ oleh Hydrilla verticillata dan Najas indica pada Tabel 2. 
Tabel 2. Kecepatan Penyerapan Hydrilla verticillata dan Najas indica

\begin{tabular}{|c|c|c|c|c|c|c|c|c|}
\hline \multirow[t]{2}{*}{$\begin{array}{c}\text { Jenis } \\
\text { tumbuhan }\end{array}$} & \multirow[t]{2}{*}{$\begin{array}{c}\text { Konsentrasi } \\
(\mathrm{mg} / \mathrm{l})\end{array}$} & \multicolumn{5}{|c|}{$\begin{array}{c}\text { Waktu Pengamatan } \\
\text { (Hari ke -) }\end{array}$} & \multirow{2}{*}{$\begin{array}{l}\text { Rata- } \\
\text { rata }\end{array}$} & \multirow{2}{*}{$\begin{array}{c}\text { Kecepatan } \\
\text { absorpsi }\end{array}$} \\
\hline & & 0 & 5 & 10 & 15 & 20 & & \\
\hline Hydrilla & B2 & 5,0 & 0,01 & 0,23 & 0,10 & 0,00 & 0,09 & 4,92 \\
\hline \multirow[t]{2}{*}{ verticillata } & B3 & 10,0 & 0,22 & 0,48 & 0,23 & 0,06 & 0,25 & 9,75 \\
\hline & B4 & 15,0 & 2,22 & 3,00 & 1,13 & 3,14 & 2,37 & 12,63 \\
\hline \multirow{3}{*}{$\begin{array}{l}\text { Najas } \\
\text { indica }\end{array}$} & B2 & 5,0 & 1,82 & 0,64 & 0,95 & 1,40 & 1,20 & 3,80 \\
\hline & B3 & 10,0 & 4,96 & 3,66 & 1,88 & 2,56 & 3,27 & 6,74 \\
\hline & B4 & 15,0 & 9,47 & 5,94 & 3,14 & 5,71 & 6,07 & 8,94 \\
\hline
\end{tabular}

Tabel 2 menunjukkan kecepatan absorpsi Hydrilla verticillata pada perlakuan B2 sebesar 4,92 mg/l sedangkan Najas indica $3,80 \mathrm{mg} / \mathrm{l}$. Pada perlakuan B3 kecepatan absorpsi sebesar $9,75 \mathrm{mg} / \mathrm{lpada}$ Hydrilla verticillata dan $6,74 \mathrm{mg} / \mathrm{l}$ pada Najas indica. Pada perlakuan B4 kecepatan absorpsi Hydrilla verticillata mencapai $12,63 \mathrm{mg} / \mathrm{l}$, sedangkan Najas indica sebesar 8,94. Secara morfologi Najas indica memiliki daun yang lebih kecil daripada Hydrilla verticillata. Henggar (2009) melaporkan bahwa tumbuhan yang memiliki ukuran lebih besar lebih baik dalam mengolah kontaminan. Perbedaan kemampuan tumbuhan dalam menyerap logam berat dapat disebabkan adanya perbedaan serangkaian proses fisiologis dan biokimiawi serta ekspresi gengen yang mengendalikan penyerapan, akumulasi dan toleransi tanaman terhadap logam (Hidayati, 2013). Menurut Srivastava (2008) bahwa penyerapan logam dapat disebabkan oleh peningkatan konsentrasi ion logam di sekitar tumbuhan.

Salah satu faktor yang mempengaruhi penyerapan logam berat adalah $\mathrm{pH}$ air. Pada penelitian ini selama waktu pengamatan $\mathrm{pH}$ air mengalami perubahan pada hari ke-5. Secara umum perubahan $\mathrm{pH}$ air ini bersifat fluktuatif tetapi masih dalam kisaran $\mathrm{pH}$ asam. Akumulasi logam berat pada tumbuhan dipengaruhi oleh banyak faktor antara lain karakteristik fisika, kimia, dan media pertumbuhan yang digunakan. Faktorfaktor tersebut meliputi $\mathrm{pH}$, kapasitas tukar ion, kejenuhan basa, pertukaran kation, dan lain-lain.
Nilai $\mathrm{pH}$ air sangat penting untuk diketahui karena menentukan mudah tidaknya ion-ion unsur hara diserap dan juga menunjukkan keberadaan unsur-unsur yang bersifat racun bagi organisme (Lopez et al, 2000). Telah dijelaskan sebelumnya bahwa hasil analisis menunjukkan kadar $\mathrm{Pb}$ didalam Hydrilla verticillata dan Najas indca sangat tinggi mencapai puluhan ribu $\mathrm{mg} / \mathrm{kg}$. Hal ini dapat disebabkan karena $\mathrm{pH}$ air pada perlakuan menjadi asam. Penurunan $\mathrm{pH}$ air secara drastis ini dapat meningkatkan kelarutan logam (Lopez et al, 2000). Menurut Sood et al (2012) bahwa biopsorpsi dipengaruhi oleh tipe jenis tanaman (genus/ spesies) yang digunakan, bentuk proses seperti: suhu, $\mathrm{pH}$, konsentrasi biomassa, dan konsentrasi logam berat. Pada penelitian ini juga dapat ditunjukkan bahwa lamanya waktu tinggal merupakan salah satu faktor yang mempengaruhi proses penyerapan logam. Menurut Salisbury dan Ross (1995) bahwa faktor eksternal yang sangat berpengaruh terhadap penyerapan logam oleh tumbuhan adalah iklim, kesuburan tanah, kesehatan tanaman, dan lamanya waktu perlakuan.

\section{SIMPULAN}

Hydrilla verticillata dan Najas indica memiliki kemampuan meremediasi logam berat timbal $(\mathrm{Pb})$ di dalam air.

Hydrilla verticillata memliki kemampuan bertahan lebih lama dalam meremediasi timbal daripada Najas indica, sebaliknya Najas indica memiliki kemampuan meremediasi terhadap timbal $(\mathrm{Pb})$ lebih cepat daripada Hydrilla verticillata. 


\section{Ucapan Terima Kasih}

Ucapan terima kasih disampaikan kepada Laboratorium Penelitian Kimia Fakultas MIPA Universitas Sriwijya, Laboratorium Riset Terpadu PascaSarjana Universitas Sriwijaya dan Program Studi Pengelolaan Lingkungan Jurusan Biologi Lingkungan Pascasarjana Universitas Sriwijaya atas bantuannya dalam penelitian ini.

\section{DAFTAR PUSTAKA}

Birmansyah. 2008. Sebaran Unsur Timbal $\left(\mathrm{Pb}^{2+}\right)$ dan Krom Heksavalen $\left(\mathrm{Cr}^{6+}\right)$ dalam Fraksi Sedimen Sub DAS Musi Bagian Hilir Propinsi Sumatera Selatan. Tesis. Program Studi Pengelolaan Lingkungan Program Pascasarjana Universitas Sriwijaya.

Giesen, W \& Sukotjo. 1991. Conservation and Management Of The Ogan Komering and Lebaks South Sumatra. Survey Report PHPA AWB Sumatra Wetland Project Report No.8. Asian Wetland Bureau Indonesia.

Ghosh, M. dan Singh,S.P. 2005. A Review on Phytoremediation of Heavy Metals and Utilization of its Byproducts. Applied Ecology and Environmental Research 3 (1): 1 -18.

Haryati, M., Purnomo, T., dan Kuntjoro, S. 2012. Kemampuan tanaman genjer (Limnocharis flava (L.)) Buch menyerap logam berat timbal $(\mathrm{Pb})$ limbah cair kertas pada biomassa dan waktu pemaparan yang berbeda. Lentera Bio (1) 3 :131-138. www. ejournal.unesa.ac.id. Diakses pada tanggal 22 November 2014.

Hidayati, N. 2005. Fitoremediasi dan Potensi Tumbuhan Hiperakumulator. Jurnal Hayati 12(1): 35-40.

Hidayati, N. 2013. Mekanisme Fisiologis Tumbuhan Hiperakumulator Logam Berat. Jurnal Teknik. Lingkungan (14) 2, Juli 2013.

Henggar, H. 2009. Potensi Tanaman Dalam Mengakumulasi Logam $\mathrm{Cu}$ pada Media Tanah Terkontaminasi Limbah Padat Industri Kertas. BS, Vol. 44, No. 1, Juni 2009 : 27 - 40. Diakses tanggal 15 Mei 2013.

Juhaeti, T., Syarif, F dan Hidayati, N. 2005. Inventarisasi Tumbuhan Potensial Untuk Fitoremediasi Lahan dan Air Terdegradasi Penambangan Emas.
Biodiversitas 6 (1): 31-33. ISSN 1412-033X.

Lakitan, B. 2004. Dasar-dasar Fisiologi Tumbuhan. Edisi 1, Cet.5. PT. RajaGrafindo Persada. Jakarta. 206 hlm.

Lambers, H., Chapin, F.S and Pons, T.J. 2010. Plant Physiological Ecology. Second Edition. Spinger.

Lelifajri, L. 2010. Adsorpsi Ion Logam $\mathrm{Cu}$ (II) menggunakan Lignin dari Limbah Serbuk Kayu Gergaji. Jurnal Rekayasa Kimia \& Lingkungan 7(3).

Lopez, A., Lazaro, N., Priego, J.M and Marques, a.m. 2000. Effect of $\mathrm{pH}$ on the biosorption of nickel and other heavy metals by Pseudomonas fluorescens 4F39. Journal of Industrial Microbiology \& Biotechnology 24: 146-151.

Maiti, S.K., Pinero, J.L.H., Oreja, J.A.G., and Santiago, D.L. 2004. Plant Based Bioremediation and Mecanism of Heavy Metal Tolerance of Plants: A Review. Proc Indian natn Sci Acad 70 (1): 1-12.

Maiti, S.K \& Shishir,J. 2008. Bioaccumulation and Translocation of Metal in Natural Vegetation Growing on Fly Ash Lagoons: A Field Study From Santaldih Thermal Power Plants, West Bengal India. Environmental Monitoring and Assessment 136: 355 - 370.

Malik, N \& Biswas, A.K. 20012. Role Of Higher Plants In Remediation Of Metal Contaminated Sites. Scientific Reviews \& Chemical Communications 2(2): $141-146$.

Marthana, W.S.M., Soeprobowati, T.R., dan Izzati, M. 2014. Bioakumulasi Timbal ( $\mathrm{Pb})$ oleh Hydrilla verticillata L.f.Royle di Danau Rawapening, Ambarawa Semarang. Jurnal Sains dan Matematika, 22(2): 52-59.

Proklamasiningsing, E dan Hemayanti. 2008. Pengaruh Logam Berat $\mathrm{Pb}$ (Plumbum) terhadap pertumbuhan Hydrilla verticillata (L.F) Royce. Skripsi. Fakultas Biologi Universitas Jenderal Soedirman.

Salisbury, F.B. dan C.W. Ross. 1995. Fisiologi Tanaman. UGM Press. Yogyakarta. 
Sandalio , L.M., Dalrzo, H.C., Gomez, Puertas, M.C.R and del-Rio, R.A. 2001. Cadmium-induced changes in the growth and oxidative metabolism of pea plants. Journal of Experimental Botany 52 (364): 2115 - 2126.

Soeprobowati, T.R. 2011. Variabilitas Keanekaragaman dan Distribusi Vertikal Diatom Danau Rawa Pening. Jurnal Sains dan Matematika. FMIPA Universitas Diponegoro. Vol. 19 (3) : $65-70$

Sood, A., Perm, L. Uniyal., Radha, P., and Amrik, S.A. 2012. Phytoremediation Potential of Aquatic Macrophyte, Azolla.AMBIO 41: 122 - 137.

Srivastava, J., Gupta, A and Chandra, H. 2008. Managing water quality with aquatic macrophytes. Rev Envirin Sci Biotechnol 7: 255-266.

Stowel, R.R., J.C. Ludwig and G. Thobanoglous. 2000. Towad the Rational Design of Aquatic Treatments of Wastewater, Departement of Civil Engineering and Land, Air and Wastewater Resources, University of California, California.
Suresh B., and G.A. Ravishankar. 2004. Phytoremediation - Anovel and Promising Approach for Environmental Clean-up. Critical Reviews in Biotechnology 24, 2-3:97 -110 .

Viobeth, B.R., Sumiyati, S., dan Sutrisno, E. 2013. Fitoremediasi Limbah Mengandung Timbal $(\mathrm{Pb})$ dan Nikel (Ni) menggunakan Tanaman Kiambang (Salvinia molesta). Jurnal Teknik Lingkungan. www.ejournalS1undip.ac.id.

Widaningrum., Miskiyah, dan Suismono. 2007. Bahaya Kontaminasi Logam Berat Dalam Sayuran Dan Alternatif Pencegahan Cemarannya. Buletin Teknologi Pascapanen Pertanian, 3.

Xing, W., Wu, H., Hao, B., Liu, G. 2013. Metal accumulation by submerge macrophytes in euthrophic lakes at the watershed scale. Environmental Science Pollution Res (20). 69997008.

Yusuf, G. 2008. Bioremediasi Limbah Rumah Tangga dengan Sistem Simulasi Tanaman Air. Jurnal Bumi Lestari. Vol 8 (2): 136-144. 